\title{
Article \\ Characteristics and Valorization Potential of Fermentation Waste of Greengage (Prunus mume)
}

\author{
Jing Wang ${ }^{1,2}$, Jingluan Wang ${ }^{1,2}$, Chongde $\mathrm{Wu}^{1,2}$, Jun Huang ${ }^{1,2}$, Rongqing Zhou ${ }^{1,2,3}$ and Yao Jin ${ }^{1,2, *}$ \\ 1 College of Biomass Science and Engineering, Sichuan University, Chengdu 610065, China; \\ 2018141501110@stu.scu.edu.cn (J.W.); wangjingluan576@outlook.com (J.W.); cdwu@scu.edu.cn (C.W.); \\ Huangjun@scu.edu.cn (J.H.); zhourqing@scu.edu.cn (R.Z.) \\ 2 Key Laboratory for Leather and Engineering of the Education Ministry, Sichuan University, \\ Chengdu 610065, China \\ 3 National Engineering Research Center of Solid-State Manufacturing, Luzhou 646000, China \\ * Correspondence: yaojin12@scu.edu.cn
}

Citation: Wang, J.; Wang, J.; Wu, C.; Huang, J.; Zhou, R.; Jin, Y.

Characteristics and Valorization Potential of Fermentation Waste of Greengage (Prunus mume). Appl. Sci. 2021, 11, 8296. https://doi.org/ 10.3390/app11188296

Academic Editor: Ioanna Vasiliadou

Received: 3 August 2021

Accepted: 31 August 2021

Published: 7 September 2021

Publisher's Note: MDPI stays neutral with regard to jurisdictional claims in published maps and institutional affiliations.

Copyright: (c) 2021 by the authors. Licensee MDPI, Basel, Switzerland. This article is an open access article distributed under the terms and conditions of the Creative Commons Attribution (CC BY) license (https:/ / creativecommons.org/licenses/by/ $4.0 /)$.

\begin{abstract}
Greengage wine is gaining increasing attention in Asia for its rich nutritional elements and medicinal value. However, the treatment of the fermentation waste after brewing is a problem that remains unsolved. This work proposed to valorize the fermentation waste extract by a simple centrifugation. The bioactive compounds of the fermentation waste were investigated, including total flavonoids, total phenols, specific phenols and volatile compounds. The antioxidant and antibacterial capacities of the waste extract were also evaluated. The results revealed that the total phenol (1.34 mg GAE/g EPW) and total flavonoid (1.17 mg RE/g EPW) of the fermentation waste extract were still considerable. The fermentation waste also showed high DPPH radical scavenging capacity $(5.39 \mu \mathrm{mol}$ TE/g EPW) and high ABTS radical scavenging capacity $(9.80 \mu \mathrm{mol}$ TE/g EPW). Both GC-MS and LC-MS analysis identified key bioactive compounds, such as linalool, terpineol, $\beta$-ionone, neochlorogenic acid and chlorogenic acid, which have high antioxidant capacity and strong, thermal-stable antibacterial capacity. All these characteristics show a promising future for valorized fermentation waste, for example, in food additives or mouthwash.
\end{abstract}

Keywords: greengage; fermentation waste; antioxidant; antibacterial; bioactive compounds

\section{Introduction}

For hundreds of years, greengage (Prunus mume), a specific variety of plum, has been used as a medical food in China, Japan and Korea to enhance the immune system and cure many diseases [1]. Extracts of greengage have been shown to have properties that fight lung, liver and other cancers [2], and researchers have discovered anti-microbial [3] and high antioxidative activity [4].

High volumes of these bioactive compounds, which work as natural antioxidants, have therapeutic potential and health benefits for humans [5]. Among these compounds are polyphenolics, flavonoids, Vitamin C, anthocyanins and carotenoids, [6] and of these, polyphenolics are the most abundant antioxidants in vegetables and fruit. [7] Researchers suggest that a long-term consumption of polyphenolic-rich food is important for preventing cancer, diabetes and other diseases [8-10]. Flavonoids, a large group of polyphenolics, show evidence of reducing the risks of developing breast, colon, lung, prostate and pancreatic tumors [11].

In 2019, greengage production of China was more than one million tons, which was all processed into preserved fruit or beverages [12]. In recent years, greengage wine has gained increasing attention, and more and more brewing plants are developing fermented greengage products. The development of fermentation technology has brought shorter production periods and better quality of wine, which is already at industrial-scale production $[13,14]$. However, after fermentation, edible parts of the fruit remained, but they were 
too acidic to be used in feedstock; therefore, they were discarded untreated, which amounts to around 1500 tons in a brewing plant with an annual wine production of 2000 tons. Such a huge amount of fermentation waste is aa severe burden on the brewing plant both economically and ecologically. Consequently, disposing of this waste will greatly promote profitability and reduce the environmental impact.

Until now, there has been no relevant research on how to deal with fermentation waste that may contain high-value compounds. Therefore, in this work, greengage fermentation waste was treated by centrifugation to obtain an extract, and its key characteristics were investigated to provide crucial reference for further valorization.

\section{Materials and Methods}

\subsection{Reagents and Standards}

All reagents and chemicals used were of analytical or HPLC grade. The ethanol for solvents, sodium carbonate, $\mathrm{NaNO}_{2}, \mathrm{Al}\left(\mathrm{NO}_{3}\right)_{3}, \mathrm{NaOH}, \mathrm{K}_{2} \mathrm{~S}_{2} \mathrm{O}_{8}$, were from Chengdu Jinshan Chemical (Chengdu, Sichuan, China), Gallic acid and rutin were from Aladdin Chemical Co. (Shanghai, China). Folin-Ciocalteu reagent, 2,20-Azio-bis(3-ethylbenzothiazoline-6sulfonic acid) diammonium salt (ABTS), 2,2-diphenyl-1-picrylhydrazyl radicals (DPPH) and 6-hydroxy-2,5,7,8- tetramethylchroman-2-carboxylic acid (Trolox) were from SigmaAldrich Chemical Co. (St. Louis, MO, USA).

\subsection{Sample Preparation and Extraction}

In this study, greengage (cultivar: "Nangao") was harvested in Dayi, Sichuan, China, and fermented to produce high-quality wine. The configurations of the fermentation process were determined and reported in our previous work [13]: Saccharomyces bayanus and Torulaspora delbrueckii were employed to initiate the repeated batch fermentation of 30 days at $25^{\circ} \mathrm{C}$. After fermentation, the greengage fruit was still complete, as shown in Figure 1. The fruit was pitted and crushed in a blender, and then $100 \mathrm{~g}$ of the edible part was centrifuged for $5 \mathrm{~min}$ at $5000 \mathrm{rpm}$, the supernatant was then sampled as the work solution, which was stored at $4{ }^{\circ} \mathrm{C}$ for further analysis, noted as the extract of fermentation waste, as shown in Figure 1. The control sample was the fresh fruit, which was prepared according to the same protocol described above.

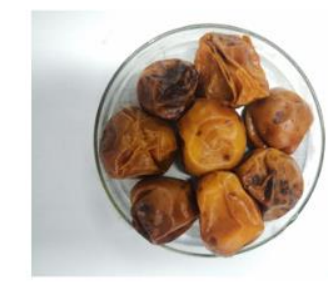

Fermentation waste of greengage
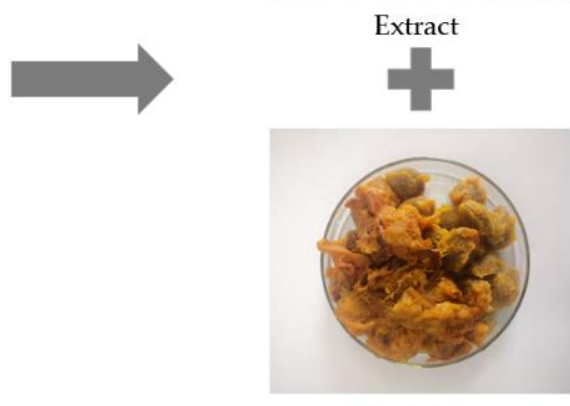

Residue

Extract

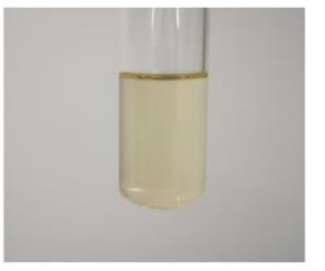

Figure 1. The fermentation of greengage waste and its extract.

\subsection{Analysis of Total Phenolic Compounds (TPC)}

The determination of total phenolic compounds was performed according to the method of Wang et al. [15] with some modifications. Before the reaction, the samples were diluted 10 times using $80 \%$ ethanol marked as work solutions. One milliliter of work 
solution was mixed with $1 \mathrm{~mL}$ Folin-Ciocalteu reagent $(1 \mathrm{~mol} / \mathrm{L})$ reacted for $2 \mathrm{~min}$, then $5 \mathrm{~mL}$ of $4 \%$ ( $4 \mathrm{~g} \mathrm{Na}_{2} \mathrm{CO}_{3}$ dissolved to $100 \mathrm{~mL}$ water) $\mathrm{Na}_{2} \mathrm{CO}_{3}$ solution was added. The reaction was then incubated at room temperature for $2 \mathrm{~h}$ in the dark. Absorption was determined using an UV-visible spectrophotometer at $760 \mathrm{~nm}$. Total phenol content was expressed as mg of gallic acid equivalent (GAE) per $\mathrm{g}$ of fresh and fermented edible parts weight (mg GAE/g EPW) using a calibration curve prepared with gallic acid as a standard.

\subsection{Analysis of Total Flavonoids Compounds (TFC)}

The total flavonoid content was determined according to the procedure described by Zhang et al. [16] with some modifications. First, $2 \mathrm{~mL}$ of work solutions was mixed with $0.4 \mathrm{~mL} \mathrm{5 \%} \mathrm{(5} \mathrm{g} \mathrm{NaNO}_{2}$ dissolved to $100 \mathrm{~mL}$ water) $\mathrm{NaNO}_{2}$ solution, and the solution was incubated for $6 \mathrm{~min}$, after which $0.4 \mathrm{~mL} 10 \% \mathrm{Al}\left(\mathrm{NO}_{3}\right)_{3}$ solution was added and then reacted for $6 \mathrm{~min}$. Then, $4 \mathrm{~mL} 4 \% \mathrm{NaOH}$ solution was mixed with the solutions. Last, ethanol was used to make sure the solutions were exactly $10 \mathrm{~mL}$. The absorbance was measured at $510 \mathrm{~nm}$ using an UV-visible spectrophotometer. A standard rutin (R) curve was prepared, thus the total flavonoid contents were described as an mg equivalent of rutin (RE) per gram of edible parts weight (mg RE/g EPW).

\subsection{Trolox Equivalent Antioxidant Capacity (TEAC) by ABTS}

TEAC analysis was performed according to the procedure described by Li et al. [17] with modifications. The ABTS cation was generated using ABTS radical (38.4 $\mathrm{mg}$ ) dissolved in $10 \mathrm{~mL}$ of water with $5 \mathrm{~mL} \mathrm{~K} \mathrm{~S}_{2} \mathrm{O}_{8}$ (70.28 $\mathrm{mg} \mathrm{K} \mathrm{K}_{2} \mathrm{~S}_{2} \mathrm{O}_{8}$ dissolved in $100 \mathrm{~mL}$ of water) solution; the mixture was incubated in the dark at room temperature for $16 \mathrm{~h}$. Thereafter, the mixture was diluted using ethanol (dilution ratio 1:50) to ensure the absorbance was adjusted to $0.7 \pm 0.02 \mathrm{~nm}$ at $734 \mathrm{~nm}$ using UV-visible spectrophotometer. Then $0.2 \mathrm{~mL}$ of work solutions were mixed with $5 \mathrm{~mL}$ ABTS radical solution and incubated for $6 \mathrm{~min}$ at room temperature. Trolox was used as a standard, and the antioxidant capacities are expressed as micromoles of Trolox equivalents (TE) per gram of edible parts weight ( $\mu \mathrm{mol} \mathrm{TE} / \mathrm{g} \mathrm{EPW})$.

\subsection{TEAC by DPPH}

Free radical-scavenging capacity of DPPH radical was measured according to the method mentioned by Hernandez-Ruiz et al. [18] with modifications. $4 \mathrm{mg}$ DPPH radical was added to $100 \mathrm{~mL}$ ethanol solution; the absorbance of the mixture was adjusted to $0.7 \pm 0.02 \mathrm{~nm}$ using an UV-visible spectrophotometer at $490 \mathrm{~nm}$. Thereafter $1 \mathrm{~mL}$ of work solutions was mixed with $5 \mathrm{~mL}$ DPPH solution and incubated in dark room at room temperature for $30 \mathrm{~min}$. Trolox was also used as a standard, and the results were expressed as micromoles of Trolox equivalents per gram of edible parts weight ( $\mu \mathrm{mol} \mathrm{TE} / \mathrm{g}$ EPW).

\subsection{Analysis of Volatile Compounds}

The method for analyzing volatile compounds in greengage fermentation waste was based on our previously defined protocol with modification [13,19,20].

GC-MS (GCMS-QP2010 SE, Shimadzu, Japan) was employed to analyze the work solution, and the volatile components in the sample were qualitatively detected by integration, and the concentration of each substance in the sample was quantitatively calculated based on the peak area and internal standard concentration. Equipment: DB-5MS $(30 \mathrm{~m} \times 0.25 \mu \mathrm{m} \times 0.25 \mu \mathrm{m})$ chromatographic column. Separation: the temperature of the column oven was $50{ }^{\circ} \mathrm{C}$; the injection temperature was $265^{\circ} \mathrm{C}$; the injection mode was split injection; and the split ratio was 50:1. Heating: the initial temperature was $50{ }^{\circ} \mathrm{C}$ for $5 \mathrm{~min}$, then increased at $3^{\circ} \mathrm{C} \mathrm{min}^{-1}$ to $180{ }^{\circ} \mathrm{C}$ for $8 \mathrm{~min}$. High purity helium gas was used as the carrier gas. The pressure was $52.7 \mathrm{KPa}$; total flow was $55.5 \mathrm{~mL} / \mathrm{min}$; solvent delay time was $1 \mathrm{~min}$; purge flow rate was $5.0 \mathrm{~mL} / \mathrm{min}$; and linear velocity was $36.1 \mathrm{~cm} / \mathrm{sec}$.

Headspace solid phase microextraction (HS-SPME): $1 \mathrm{~g}$ of $\mathrm{NaCl}$ measured in advance and added to the headspace bottle; $1 \mathrm{~mL}$ of the sample was pipetted and added to the 
headspace bottle to saturate the solution and promote the volatilization of components. To this was added $20 \mu \mathrm{L}$ of internal standard (with a concentration of $0.073 \mathrm{~g} / 100 \mathrm{~mL}$ 2-octanol) and $0.0069 \mathrm{~g} / 100 \mathrm{~mL}$ methyl octanoate solution. The bottle was sealed with a silica gel plug. The headspace vial was then placed in a $60^{\circ} \mathrm{C}$ water bath, pre-equilibrated for $10 \mathrm{~min}$. A solid phase extraction needle was then inserted into the headspace vial, and the microextraction head was extended to expose the upper part of the headspace vial at $60{ }^{\circ} \mathrm{C}$ to extract and adsorb for $50 \mathrm{~min}$.

\subsection{Analysis of Bioavtive Compounds in Liquid Phase}

The separation of the bioactive compounds from the extracts of the edible parts of the fermentation waste was performed using a LC-MS system based on Ultimate 3000 (Thermo Fisher Scientific, Waltham, MA, USA) coupled online to a Q Exactive Plus mass spectrometer (Thermo Fisher Scientific, Waltham, MA, USA). $10 \mathrm{~g}$ of edible parts of the waste was soaked in $20 \mathrm{~mL} 80 \%$ ethanol $(v / v)$ for $24 \mathrm{~h}$. Afterwards, the extract was collected and centrifuged at $5000 \mathrm{rpm}$ for $5 \mathrm{~min}$. The supernatant was then filtered with a $0.22 \mu \mathrm{m}$ membrane and diluted 50 times as the work solution in this analysis. The method of analyzing phenolic compounds of fermentation waste was then referred to Yu et al. [21]. Data processing was performed using Compound Discoverer software (Thermo Fisher Scientific, Waltham, MA, USA).

The experiment was conducted on a Hypersil GOLD column $(2.1 \times 100 \mathrm{~mm}$, particle size $1.9 \mu \mathrm{m}$ ). Solvent A (Aqueous solution containing $0.1 \%$ formic acid) and solvent $B$ (Acetonitrile solution containing $0.1 \%$ formic acid) were used for gradient elution. The gradient was formed as follows: 0 to $2 \mathrm{~min} 2 \% \mathrm{~B}, 2$ to $12 \mathrm{~min} 2-30 \% \mathrm{~B}, 12$ to $20 \mathrm{~min} 30-98 \%$ B, 20 to $22 \mathrm{~min} 98 \%$ B, 22 to $22.198-2 \%$ B, 22.1 to $252 \%$ B. The flow rate of the mobile phase was $0.300 \mathrm{~mL} / \mathrm{min}$; the equilibrated column temperature was $30{ }^{\circ} \mathrm{C}$, and the injection volume was $2 \mu \mathrm{L}$. High-resolution mass spectrometry with electrospray ionization (ESI) set positive and negative scanning mode and in full MS/DD-MS2. It adopted full MS scan with a scan range of 100 to $1500 \mathrm{~m} / \mathrm{z}$ and a resolution of 70,000. Automatic gain control (AGC) target was $1 \times 10^{6}$ and maximum injection time was $100 \mathrm{~ms}$. The spray voltage was kept at $3.5 \mathrm{kV}$ in positive scanning mode and $2.5 \mathrm{kV}$ in negative mode, with the capillary temperature being set to $320^{\circ} \mathrm{C}$. The sheath gas was 35 arb and the aux gas was 10 arb.

\subsection{Analysis of Antibacterial Capacity}

The antibacterial capacity of work solution was evaluated by the inhibitory zone diameters according to the literature [22]. Three model strains were employed: Staphylococcus aureus; Escherichia coli; Bacillus subtilis. The culture medium was prepared as follow: beef extract $3 \mathrm{~g}$, peptone $10 \mathrm{~g}, \mathrm{NaCl} 5 \mathrm{~g}$, agar 15-20 g, distilled water $1000 \mathrm{~mL}, \mathrm{pH}=7.0-7.2$, autoclaved at $121{ }^{\circ} \mathrm{C}$ for $30 \mathrm{~min}$. As for the analysis, the culture medium was poured into a Petri dish. After its solidification, the suspension of the bacteria strains of $0.1 \mathrm{~mL}$ was dropped into the Petri dish using a micropipette with a sterilized tip and then spread evenly with a spreader. A sterile disc paper (6 $\mathrm{mm}$ diameter) was dipped into the work solutions. The Petri dish was then incubated for $24 \mathrm{~h}$ at $37^{\circ} \mathrm{C}$. The clear zones (inhibitory zones) of each disc paper were measured. Each work solution was tested in triplicate, with distilled water as a blank control.

\subsection{Statistical Analysis}

Triplicate experiments were conducted on each sample and the data was represented in the form of mean relative standard deviation (RSD). One-way analysis of variance (ANOVA) was conducted using SPSS software (version 17.0; SPSS Inc., Chicago, IL, USA). ANOVA with Duncan's test was performed to evaluate significant differences for different samples, and a significant difference was defined as $p<0.05(n=3)$. 


\section{Results}

\subsection{Total Phenolic and Flavonoid Contents}

Phenolic compounds are the primary secondary metabolites in plants and can act as natural antioxidants. They reduce free radical formation caused by different kinds of stress and thus they show their protective effects in plants, and reports show that they could have similar effects in humans [5,23]. The total phenolic contents obtained from the fresh greengage and the fermentation waste are shown in Figure 2.

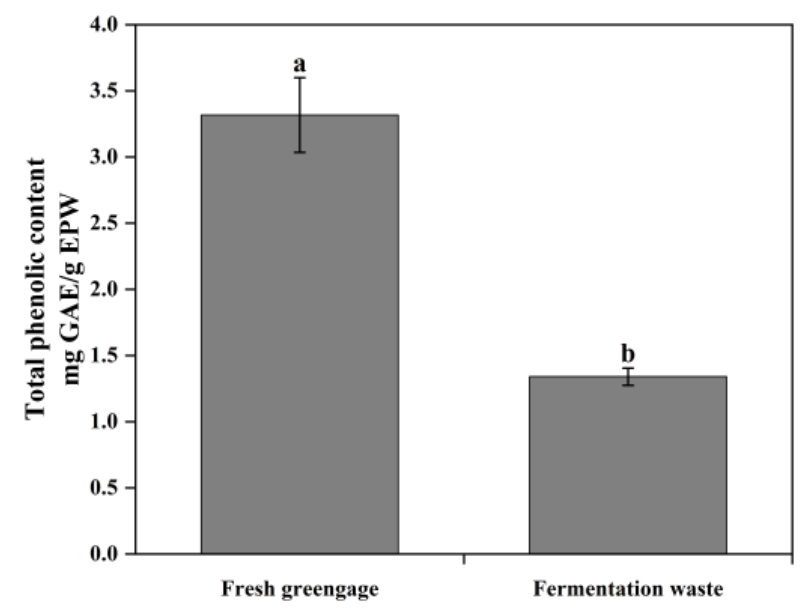

Figure 2. Total phenolic contents of fresh greengage and its fermentation waste. The data are shown as the mean values of three determinations $(n=3) \pm$ standard deviation (error bars). Different letters indicate that they are significantly different at $p<0.05$ according to ANOVA analysis.

Compared to the fresh fruit, an obvious decrease in the phenolic compound content in the fermentation waste was revealed. The exact values are $3.32 \mathrm{mg}$ GAE/g EPW for fresh greengage against $1.34 \mathrm{mg}$ GAE/g EPW for fermentation waste, about $59.6 \%$ less. As one of the main products of secondary metabolism, phenolic compounds are often enriched after fermentation since various kinds of secondary metabolism occur during fermentation [24]. However, phenolic compounds are mostly polar compounds and their polarity is close to that of esters and alcohols [25] which means that they are more easily dissolved in ester or alcohol solutions than water. Moreover ethanol is a better organic solvent for extracting phenolic compounds in plants compared to methanol and acetone [26]. Therefore, at the end of greengage wine production, the phenolic compounds were dissolved into the phase of ethanol (wine), resulting in their depletion in the fermentation waste.

Phenolic compound content is one of the important factors in the fruit-based investigation. Murillo, Britton and Durant [5] reported 1.88 and $1.08 \mathrm{mg} \mathrm{GAE/g} \mathrm{FW(Fresh} \mathrm{Weight)}$ for red and yellow plums, respectively. In research into edible wild fruit, Shan et al. [27] reported $1.13 \mathrm{mg}$ GAE/g FW from round plums. Compared with this relevant research in the literature, the content of phenolic compounds in the fermentation waste was still high enough to be valorized.

Figure 3 demonstrates the total flavonoid content of both fresh fruit and the fermentation waste. The results show $1.70 \mathrm{mg} \mathrm{RE} / \mathrm{g}$ EPW for fresh fruit and $1.17 \mathrm{mg} \mathrm{RE} / \mathrm{g}$ EPW for fermentation waste, a decrease of $31.45 \%$, indicating lower depletion compared to that of total phenolic compounds. The results may be explained by the fact that flavonoids are semi-polar compounds: their non-polar core structure is modified by various polar hydroxyl groups and carbohydrate moieties, and flavonoids can readily be extracted using polar organic solvents such as methanol, ethanol, acetonitrile and acetone [11,28]. Consequently, larger amounts of flavonoids than other phenolic compounds may remain in the fermented marc. Clearly, the flavonoid content in the fermentation waste was far from exhausted as previous examples from the literature show. Ga Hee Jang et al. [29] reported a value of $1.49 \mathrm{mg} / \mathrm{g}$ DW (Dry Weight) from Chinese plum, and another study obtained a 
value of $2.5 \mathrm{mg}$ QE (Quercetin Equivalent)/g FW for yellow plum and $2.3 \mathrm{mg}$ QE/g FW for red plum [18].

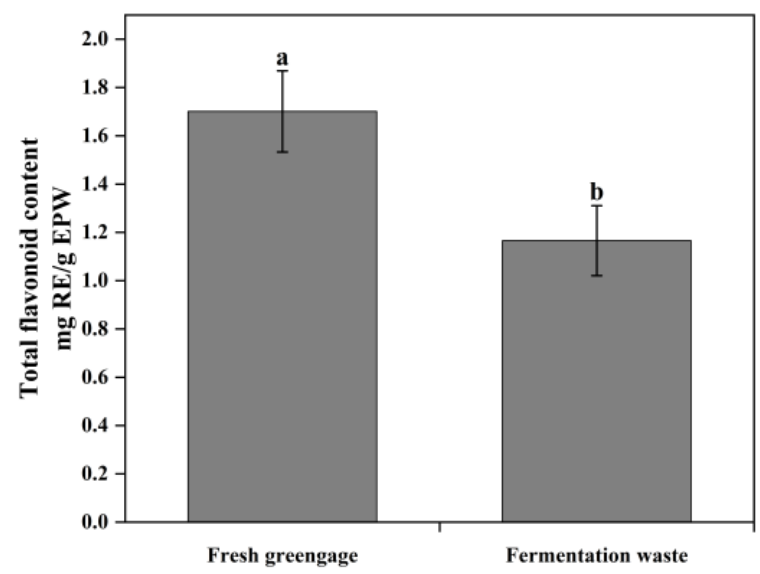

Figure 3. Total flavonoid contents of fresh greengage and its fermentation waste. The data are shown as the mean values of three determinations $(n=3) \pm$ standard deviation (error bars). Different letters indicate that they are significantly different at $p<0.05$ according to ANOVA analysis.

\subsection{Identification of Bioactive Compounds}

\subsubsection{Volatile Compounds}

In this section, the volatile compounds of fermentation waste extract were analyzed to identify the bioactive compounds both qualitatively and quantitatively. A total of 41 substances were identified and clustered into 5 groups according to chemical structure: 11 alcohols, 8 aldehydes and ketones, 4 acids and anhydrides, 12 esters and 6 others (The complete compound list is in Table S1). As shown in Figure 4, the waste sample still contained a large amount of volatile compounds, especially aldehydes and ketones. Our previous work, however, showed that the alcohols and esters were the most abundant compounds in the greengage wine [13]. It can be speculated that the retention ratio of the aldehydes and ketones was higher than that of alcohols and esters in the fermented marc.

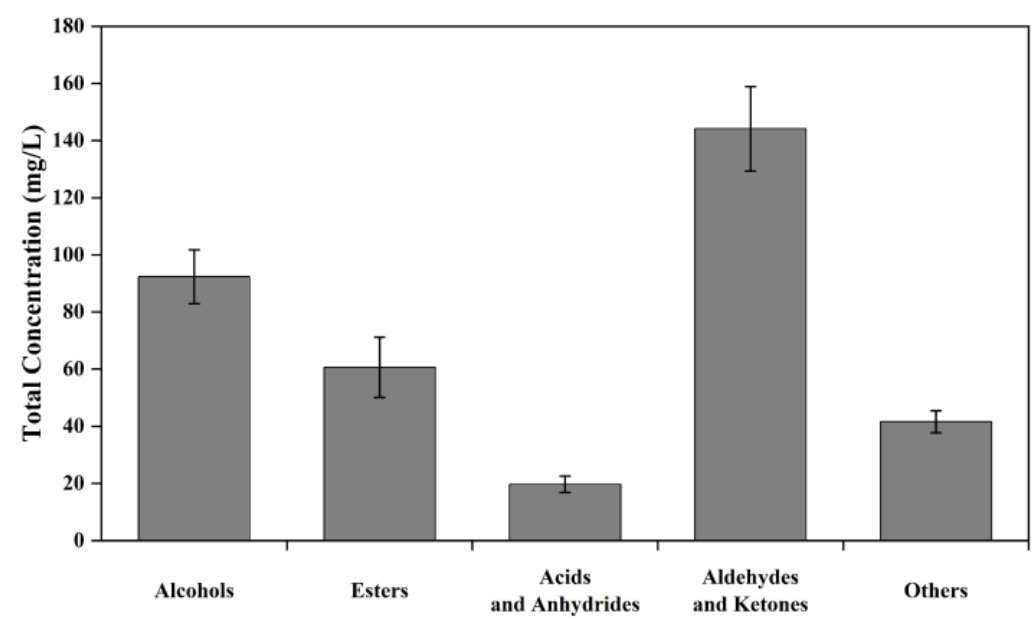

Figure 4. Total concentration of the volatile compounds of the waste sample. The data are shown as the mean values of three determinations $(n=3) \pm$ standard deviation (error bars).

In addition, among the 41 identified substances in the fermentation waste, several wellknown bioactive compounds with strong antibacterial capacity were revealed. As shown in Table 1, these are linalool [30], dihydrolinalool [30], terpineol [29], methyl salicylate [31], 2-Butanone, 4-(2,6,6-trimethyl-1-cyclohexen-1-yl [32], $\delta$-Nonalactone and $\beta$-ionone [32]. Moreover, terpineol and the ionones were also reported to possess good anticancer ef- 
fects [33]. Specifically, the relevant literature has shown that $\alpha$-terpineol had a good inhibitory effect on Escherichia coli when the content was above $0.78 \mathrm{mg} / \mathrm{L}$ [34]. According to the test results of green plum juice, $\beta$-ionone and dihydro $\beta$-ionone showed a broadspectrum antibacterial effect at $6.4 \mathrm{mg} / \mathrm{L}$ [32]. The above two bioactive compounds in the waste sample far exceeded the antibacterial threshold, implying a good antibacterial capacity, which will be confirmed in Section 3.4.

Table 1. Key Bioactive Compounds Found in the Fermentation Waste Extract.

\begin{tabular}{cccc}
\hline Numbers & CAS & Substracts & Concentration (mg/L) \\
\hline 1 & $78-70-6$ & Linalool & $14.33 \pm 1.09$ \\
2 & $2270-57-7$ & 3,7-Dimethyl-6-octen-3-ol & $9.26 \pm 1.06$ \\
3 & $10482-56-1$ & Terpineol & $25.19 \pm 1.87$ \\
4 & $119-36-8$ & Methyl salicylate & $4.803 \pm 0.81$ \\
5 & $17283-81-7$ & $4-(2,6,6-$ trimethyl-1-cyclohexen-1-yl)butan-2-one & $11.08 \pm 0.94$ \\
6 & $3301-94-8$ & $\delta$-Nonalactone & $9.94 \pm 0.29$ \\
7 & $14901-07-6$ & 3-ionone & $24.33 \pm 5.68$ \\
\hline
\end{tabular}

\subsubsection{Phenolic Compounds}

In this section, the phenolic compounds in the fermentation waste extract were identified by LC-MS so that the specific bioactive compounds could be explored further. According to LC-MS analyses, 16 phenolic substances were detected (Table S2), four of which became widely known in recent years for their significant antioxidant and antibacterial capacity. As revealed in Table 2, neochlorogenic acid, chlorogenic acid, 7-Hydroxycoumarine and 3-O-Feruloylquinic acid were found in the extract. The literature [35] shows that the DPPH radical scavenging activity of neochlorogenic acid and chlorogenic acid are as high as $797.3 \mathrm{mmol} \mathrm{TE} / \mathrm{g}$ and $748.8 \mathrm{mmol} \mathrm{TE} / \mathrm{g}$, respectively. 7-Hydroxycoumarine has also been proven to have a good antibacterial effect, even $100 \%$ under acidic conditions [36]. In addition, 3-O-Feruloylquinic acid was confirmed to be an effective antioxidant [37]. All these phenolic compounds endow fermentation waste fairly good antioxidant and antibacterial capacity, which will be certificated later in this work.

Table 2. Key Phenolic Compounds Found in the Fermentation Waste Extract.

\begin{tabular}{cccccc}
\hline Numbers & RT (min) & Compound Name & $\begin{array}{c}m / z \\
\text { Calculated }\end{array}$ & $\begin{array}{c}m / z \\
\text { Experimental }\end{array}$ & Formula \\
\hline 1 & 5.576 & Neochlorogenic acid & 353.30078 & 353.08801 & $\mathrm{C}_{16} \mathrm{H}_{18} \mathrm{O}_{9}$ \\
2 & 7.017 & Chlorogenic acid & 353.30078 & 353.08765 & $\mathrm{C}_{16} \mathrm{H}_{18} \mathrm{O}_{9}$ \\
3 & 5.576 & 7-Hydroxycoumarine & 161.13420 & 163.03923 & $\mathrm{C}_{9} \mathrm{H}_{6} \mathrm{O}_{3}$ \\
4 & 7.114 & 3-O-Feruloylquinic acid & 367.32736 & 367.10349 & $\mathrm{C}_{17} \mathrm{H}_{20} \mathrm{O}_{9}$ \\
\hline
\end{tabular}

\subsection{Antioxidant Capacity}

In this section, the antioxidant capacity of the waste sample was evaluated by both ABTS and DPPH methods. The samples of fresh greengage were also tested to provide a comparative references.

Figure 5 shows the DPPH radical scavenging of fresh fruit and fermentation waste. The lower value ifor the fermentation waste shows that the fresh greengage exhibited a higher DPPH radical scavenging capacity than the waste $(7.84 \mu \mathrm{mol} \mathrm{TE} / \mathrm{g}$ EPW and $5.39 \mu \mathrm{mol}$ TE/g EPW, respectively). Nevertheless, $5.39 \mu \mathrm{mol} \mathrm{TE} / \mathrm{g}$ EPW was still far from exhausted since lower values of around $3 \mu \mathrm{mol}$ TE/g EPW for plum fruit are previously reported in the literature [38], which makes the valorization of the waste necessary. 


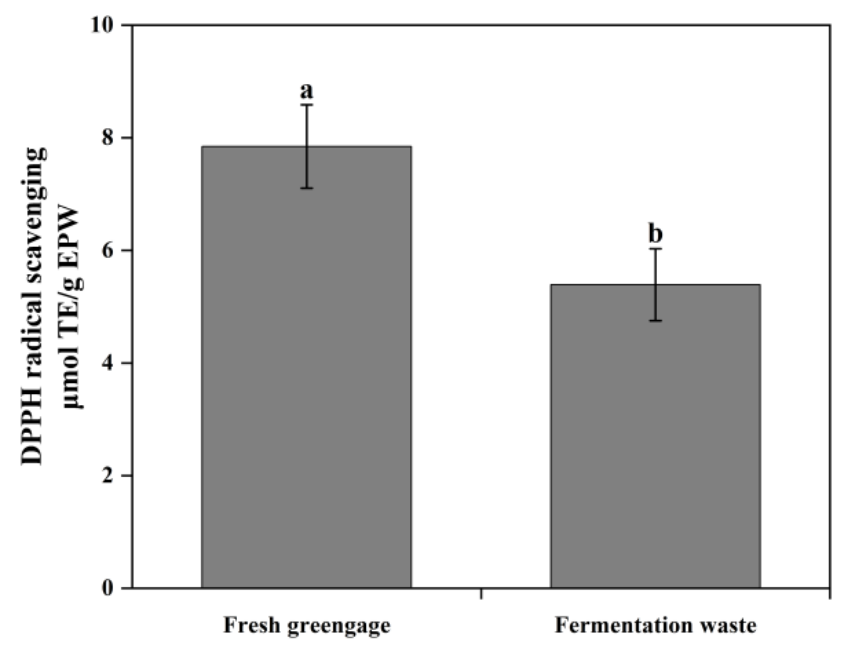

Figure 5. DPPH radical scavenging of fresh greengage and its fermentation waste. The data are shown as the mean values of three determinations $(n=3) \pm$ standard deviation (error bars). Different letters indicate that they are significantly different at $p<0.05$ according to ANOVA analysis.

The results of ABTS radical scavenging are illustrated in Figure 6. Similar remarks can be drawn: the fermentation waste again presented lower antioxidant capacity than the fresh one, with the value of $9.80 \mu \mathrm{mol} / \mathrm{g}$ EPW, while previous works reported around $6 \mu \mathrm{mol} \mathrm{TE} / \mathrm{g}$ FW for yellow plum [38,39].

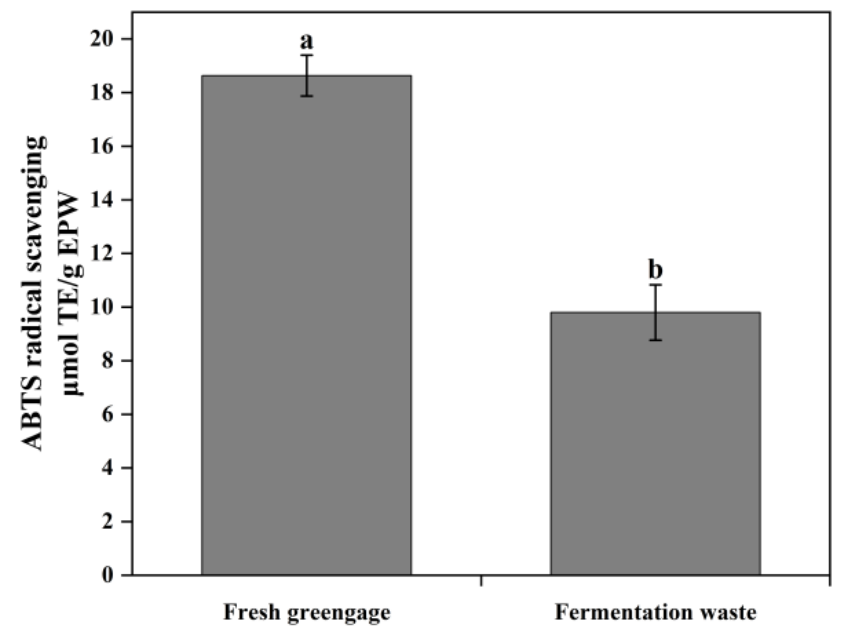

Figure 6. ABTS radical scavenging of fresh greengage and its fermentation waste. The data are shown as the mean values of three determinations $(n=3) \pm$ standard deviation (error bars). Different letters indicate that they are significantly different at $p<0.05$ according to ANOVA analysis.

In general, the position and counts of the hydroxyl groups on the aromatic rings of the phenolic compounds affect the activity of free radicals; thus phenolic compounds (including flavonoids) contribute to free radial scavenging [40]. In this case, the fermentation waste had a lower TPC and TFC value of than for fresh fruit, which resulted in lower DPPH and ABTS radical scavenging.

\subsection{Antibacterial Capacity}

In Section 3.2, several key bioactive compounds were identified in the waste sample that showed high antibacterial potential; in this section, we provide the proof. To exclude the effect of the medium's $\mathrm{pH}$ on antibacterial capacity, a comparative control was also employed using a citric acid solution with a $\mathrm{pH}$ of 2.2 (the same $\mathrm{pH}$ as that of the waste), based on a previous report showing citric acid to be the main organic acid in greengage [41]. 
Figure 7 illustrates the average inhibitory zone diameters for a citric acid solution $(\mathrm{pH}=2.2)$ and fermentation waste extract. The inhibitory effect of the waste extract on all the three strains was quite remarkable since the zone diameters were all higher that $17 \mathrm{~mm}$. Otherwise, the citric acid solution showed only a weak inhibitory effect on Bacillus subtilis, and no inhibition for Staphylococcus aureus or Escherichia coli. These results suggested that the fermentation waste indeed possessed strong antibacterial capacity, which did not result from the excessive acidity.

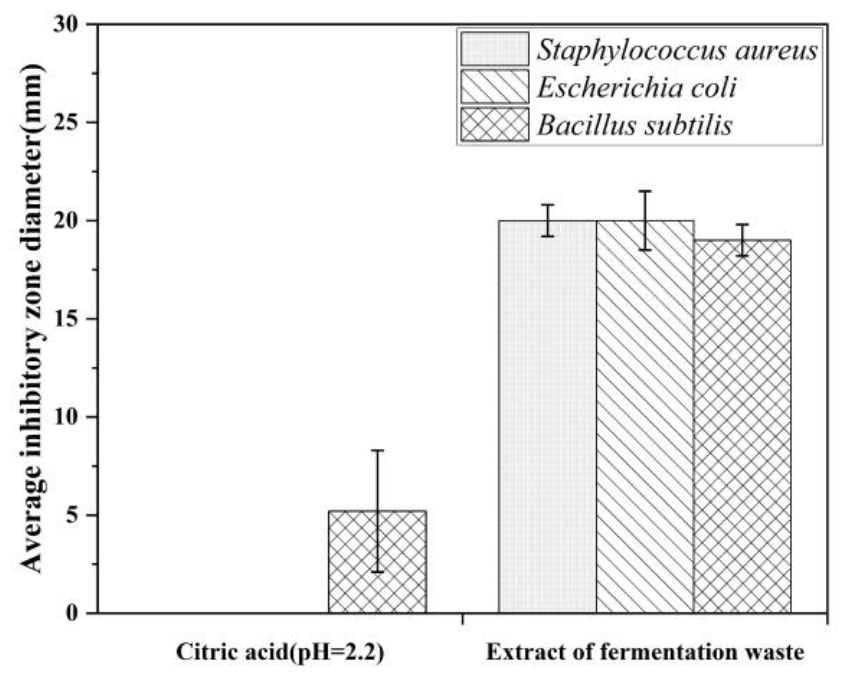

Figure 7. Bacteriostatic effect of the fermentation waste of greengage compared to citric acid solution. The data are shown as the mean values of three determinations $(n=3) \pm$ standard deviation (error bars).

To assess antibacterial capacity in the context of thermal stability, the fermentation waste was heated to $121^{\circ} \mathrm{C}$ for different durations before the test. As shown in Figure 8, the size of the inhibition zone remained quite constant for all the three strains after heating from 5 to $30 \mathrm{~min}$, suggesting that the active compounds in the fermentation waste were thermally stable.

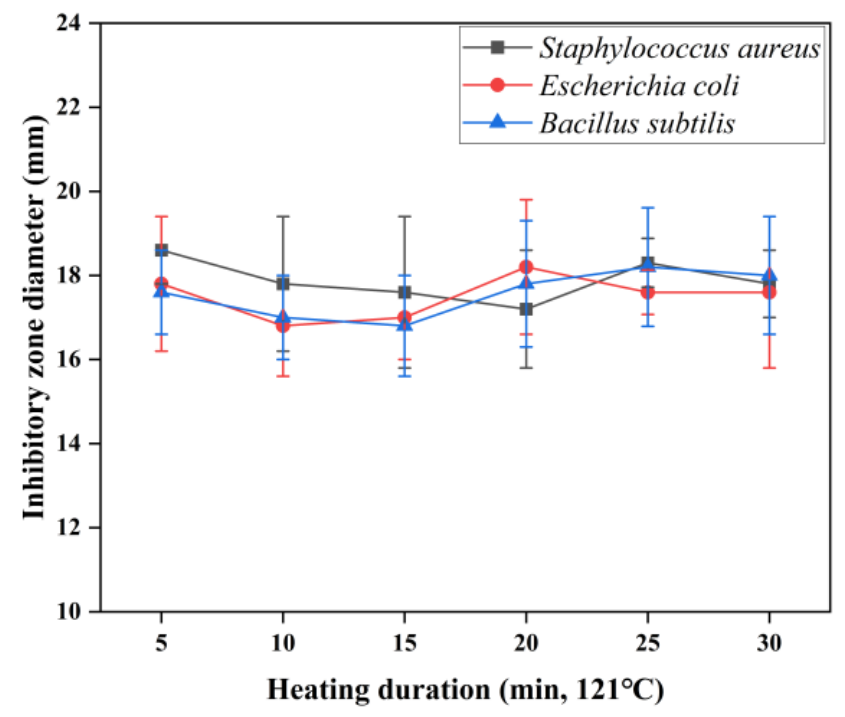

Figure 8. The impact of heating on the bacteriostatic effect of greengage fermentation waste. The data are shown as the mean values of three determinations $(n=3) \pm$ standard deviation (error bars). 


\section{Discussion}

The greengage variety "Nangao" from Dayi (Sichuan, China) was used in this work. As a fruit well known to be rich in bioactive compounds, the main characteristics of the different greengage varieties had already been investigated [42-44]. Being different in a narrow range, they were quite comparable in total content of acid, sugar, vitamin C, proteins, amino acids, flavonoids and phenols. Those comparative investigations ensured that this work would provide important guidance for the majority of greengage wine breweries even though different varieties are employed in fermentation.

Moreover, by focusing on greengage fermentation waste, the bioactive compounds found in this work are quite consistent with the previously mentioned work on greengage fruit [45-47]. Though they have different compositions, the key bioactive compounds (linalool, terpineol, $\beta$-ionone, neochlorogenic acid and chlorogenic acid) were present and well identified in the samples of this work and those in the literature. This not only consolidated the previous revelations about bioactive greengage compounds, but also implied that they were partially retained in the fermentation waste.

As for the potential applications of fermentation waste, various industrial sectors can be involved. Although the total phenol content and total flavonoid content of the fermentation waste extract were lower than the fresh greengage extract, they were still high enough to be recovered. According to the literature [48,49], the extract of such bioactive compound richness can deliver human health benefits such as enhancing immunity, suppressing tumors, resisting infection, reducing cholesterol and delaying aging. Therefore, it may serve as the active ingredient in medical or cosmetic products.

In addition, the extract proved to have a strong antibacterial ability that was thermal stable. This characteristic may contribute in the food industry as food preservative or additive, or in the production of personal hygiene products such as mouthwash. The results of this work may also inspire further applications of such fermentation waste for sustainable development.

\section{Conclusions}

In this work, the fermentation waste of greengage was simply centrifuged to obtain its extract, of which the characteristics were analyzed to provide crucial guidance for its further valorization.

The fermentation waste of greengage has been confirmed to contain considerable total phenols and flavonoids. As revealed by both GC-MS and LC-MS analysis, the key bioactive compounds (linalool, terpineol, $\beta$-ionone, neochlorogenic acid and chlorogenic acid) were identified, which gave the fermentation waste its high antioxidant capacity and strong, thermally stable antibacterial ability. These features assure that the valorization of greengage fermentation waste has a promising future.

Supplementary Materials: The complete list of volatile compounds of the fermentation waste identified by GC-MS is shown in Table S1. The complete list of phenolic components of the fermentation waste identified by LC-MS is shown in Table S2.

Author Contributions: J.W. (Jing Wang): Investigation, Formal analysis, Writing-original draft. J.W. (Jingluan Wang): Investigation, Formal analysis. C.W.: Resources, Writing-review and editing. J.H.: Methodology, Resources. R.Z.: Resources, Writing-review and editing. Y.J.: Conceptualization, Writing-review and editing, Supervision, Funding; acquisition. All authors have read and agreed to the published version of the manuscript.

Funding: This work was sponsored by National Natural Science Foundation of China (Grant number: 21978175), Sichuan Science and Technology Program (Grant number: 2019YJ0109) and Fundamental Research Funds for the Central Universities of China (Grant number: YJ201835).

Conflicts of Interest: The authors declare no conflict of interest. 


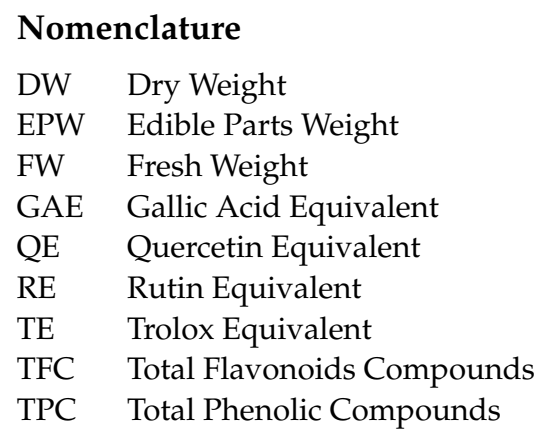

\section{References}

1. Jung, B.-G.; Ko, J.-H.; Cho, S.-J.; Koh, H.-B.; Yoon, S.-R.; Han, D.-U.; Lee, B.-J. Immune-Enhancing Effect of Fermented Maesil (Prunus mume Siebold \& Zucc.) with Probiotics against Bordetella Bronchiseptica in Mice. J. Vet. Med. Sci. 2010, 72, 1195-1202. [CrossRef] [PubMed]

2. Bailly, C. Anticancer Properties of Prunus mume Extracts (Chinese Plum, Japanese Apricot). J. Ethnopharmacol. 2020, $246,112215$. [CrossRef]

3. Seneviratne, C.J.; Wong, R.W.K.; Hägg, U.; Chen, Y.; Herath, T.D.K.; Lakshman Samaranayake, P.; Kao, R. Prunus mume Extract Exhibits Antimicrobial Activity against Pathogenic Oral Bacteria: Prunus mume Extract Exhibits Antimicrobial Activity. Int. J. Paediatr. 2011, 21, 299-305. [CrossRef] [PubMed]

4. Mitani, T.; Horinishi, A.; Kishida, K.; Kawabata, T.; Yano, F.; Mimura, H.; Inaba, N.; Yamanishi, H.; Oe, T.; Negoro, K.; et al. Phenolics Profile of Mume, Japanese Apricot ( Prunus mume Sieb. et Zucc.) Fruit. Biosci. Biotechnol. Biochem. 2013, 77, 1623-1627. [CrossRef]

5. Durant, A.; Murillo, E.; Britton, G. Antioxidant Activity and Polyphenol Content in Cultivated and Wild Edible Fruits Grown in Panama. J. Pharm. Bioall. Sci. 2012, 4, 313. [CrossRef]

6. Jia, Z.; Dumont, M.-J.; Orsat, V. Encapsulation of Phenolic Compounds Present in Plants Using Protein Matrices. Food Biosci. 2016, 15, 87-104. [CrossRef]

7. Nardini, M.; Garaguso, I. Characterization of Bioactive Compounds and Antioxidant Activity of Fruit Beers. Food Chem. 2020, 305, 125437. [CrossRef]

8. Del Rio, D.; Rodriguez-Mateos, A.; Spencer, J.P.E.; Tognolini, M.; Borges, G.; Crozier, A. Dietary (Poly)Phenolics in Human Health: Structures, Bioavailability, and Evidence of Protective Effects Against Chronic Diseases. Antioxid. Redox Signal. 2013, 18, 1818-1892. [CrossRef]

9. Tome-Carneiro, J.; Larrosa, M.; Gonzalez-Sarrias, A.; Tomas-Barberan, F.A.; Teresa Garcia-Conesa, M.; Carlos Espin, J. Resveratrol and Clinical Trials: The Crossroad from In Vitro Studies to Human Evidence. Curr. Pharm. Des. 2013, 19, 6064-6093. [CrossRef]

10. Grosso, G.; Micek, A.; Godos, J.; Pajak, A.; Sciacca, S.; Galvano, F.; Giovannucci, E.L. Dietary Flavonoid and Lignan Intake and Mortality in Prospective Cohort Studies: Systematic Review and Dose-Response Meta-Analysis. Am. J. Epidemiol. 2017, 185, 1304-1316. [CrossRef]

11. Lei, Z.; Sumner, B.W.; Bhatia, A.; Sarma, S.J.; Sumner, L.W. UHPLC-MS Analyses of Plant Flavonoids. Curr. Protoc. Plant Biol. 2019, 4, e20085. [CrossRef]

12. Yu, Y.; Xu, Y.; Yu, Y.; Yang, F.; Zou, B.; Hu, Y.; Zhu, Y. The Active Ingredient and Nutrition Health Effect of Organic Acids in Prunus mume. China Fruit Veg. 2020, 40, 24-28. [CrossRef]

13. Liu, J.; Liu, M.; Ye, P.; He, C.; Liu, Y.; Zhang, S.; Huang, J.; Zhou, J.; Zhou, R.; Cai, L. Characterisation of the Metabolite Profile and Microbial Community of Repeated Batch and Coculture-Fermented Greengage Wine. Process Biochem. 2021, 109, 117-129. [CrossRef]

14. Xiong, Q.; Xiao, S.; Huang, J.; Zhou, R.; Zhang, L.; Jin, Y. Microfiltration of greengage wine: Membrane fouling analysis and quality evaluation. Food Ferment. Ind. 2020, 46, 77-83. [CrossRef]

15. Wang, X.; Xie, K.; Zhuang, H.; Ye, R.; Fang, Z.; Feng, T. Volatile Flavor Compounds, Total Polyphenolic Contents and Antioxidant Activities of a China Gingko Wine. Food Chem. 2015, 182, 41-46. [CrossRef]

16. Zhang, H.-F.; Zhang, X.; Yang, X.-H.; Qiu, N.-X.; Wang, Y.; Wang, Z.-Z. Microwave Assisted Extraction of Flavonoids from Cultivated Epimedium Sagittatum: Extraction Yield and Mechanism, Antioxidant Activity and Chemical Composition. Ind. Crop. Prod. 2013, 50, 857-865. [CrossRef]

17. Li, X.; Lin, J.; Gao, Y.; Han, W.; Chen, D. Antioxidant Activity and Mechanism of Rhizoma cimicifugae. Chem. Cent. J. 2012, 6, 140. [CrossRef] [PubMed]

18. Hernández-Ruiz, K.L.; Ruiz-Cruz, S.; Cira-Chávez, L.A.; Gassos-Ortega, L.E.; Ornelas-Paz, J.D.J.; Del-Toro-Sánchez, C.L.; Márquez-Ríos, E.; López-Mata, M.A.; Rodríguez-Félix, F. Evaluation of Antioxidant Capacity, Protective Effect on Human Erythrocytes and Phenolic Compound Identification in Two Varieties of Plum Fruit (Spondias Spp.) by UPLC-MS. Molecules 2018, 23, 3200. [CrossRef] 
19. Xiong, Q.-M.; Liu, J.; Liu, M.; Shen, C.-H.; Yu, X.-C.; Wu, C.-D.; Huang, J.; Zhou, R.-Q.; Jin, Y. Fouling Analysis and Permeate Quality Evaluation of Mulberry Wine in Microfiltration Process. RSC Adv. 2019, 10, 655-665. [CrossRef]

20. Yang, M.; Huang, J.; Zhou, R.; Qi, Q.; Peng, C.; Zhang, L.; Jin, Y.; Wu, C. Characterizing the Microbial Community of Pixian Doubanjiang and Analysing the Metabolic Pathway of Major Flavour Metabolites. Food Sci. Technol. 2021, 143, 111170. [CrossRef]

21. Yu, J.; Li, W.; You, B.; Yang, S.; Xian, W.; Deng, Y.; Huang, W.; Yang, R. Phenolic Profiles, Bioaccessibility and Antioxidant Activity of Plum (Prunus salicina Lindl). Food Res. Int. 2021, 143, 110300. [CrossRef]

22. Adriani, N.H.; Rahayu, D.U.C.; Saepudin, E. Activity of Hydrogenated Curcuminoid on Pd/C Catalyst and Its Antibacterial Activity against Staphylococcus Aureus and Streptococcus Mutans. IOP Conf. Ser. Mater. Sci. Eng. 2020, 902, 012068. [CrossRef]

23. Hidalgo, M.; Sánchez-Moreno, C.; de Pascual-Teresa, S. Flavonoid-Flavonoid Interaction and Its Effect on Their Antioxidant Activity. Food Chem. 2010, 121, 691-696. [CrossRef]

24. Ruiz, A.; Hermosín-Gutiérrez, I.; Mardones, C.; Vergara, C.; Herlitz, E.; Vega, M.; Dorau, C.; Winterhalter, P.; von Baer, D. Polyphenols and Antioxidant Activity of Calafate (Berberis microphylla) Fruits and Other Native Berries from Southern Chile. J. Agric. Food Chem. 2010, 58, 6081-6089. [CrossRef]

25. Ciulu, M.; Cádiz-Gurrea, M.; Segura-Carretero, A. Extraction and Analysis of Phenolic Compounds in Rice: A Review. Molecules 2018, 23, 2890. [CrossRef]

26. Sepahpour, S.; Selamat, J.; Abdul Manap, M.; Khatib, A.; Abdull Razis, A. Comparative Analysis of Chemical Composition, Antioxidant Activity and Quantitative Characterization of Some Phenolic Compounds in Selected Herbs and Spices in Different Solvent Extraction Systems. Molecules 2018, 23, 402. [CrossRef] [PubMed]

27. Shan, S.; Huang, X.; Shah, M.H.; Abbasi, A.M. Evaluation of Polyphenolics Content and Antioxidant Activity in Edible Wild Fruits. BioMed Res. Int. 2019, 2019, 1-11. [CrossRef] [PubMed]

28. Paz, M.; Gúllon, P.; Barroso, M.F.; Carvalho, A.P.; Domingues, V.F.; Gomes, A.M.; Becker, H.; Longhinotti, E.; Delerue-Matos, C. Brazilian Fruit Pulps as Functional Foods and Additives: Evaluation of Bioactive Compounds. Food Chem. 2015, 172, 462-468. [CrossRef] [PubMed]

29. Jang, G.H.; Kim, H.W.; Lee, M.K.; Jeong, S.Y.; Bak, A.R.; Lee, D.J.; Kim, J.B. Characterization and Quantification of Flavonoid Glycosides in the Prunus genus by UPLC-DAD-QTOF/MS. Saudi J. Biol. Sci. 2018, 25, 1622-1631. [CrossRef]

30. Guo, F.; Liang, Q.; Zhang, M.; Chen, W.; Chen, H.; Yun, Y.; Zhong, Q.; Chen, W. Antibacterial Activity and Mechanism of Linalool against Shewanella putrefaciens. Molecules 2021, 26, 245. [CrossRef]

31. Zhang, W.; Chen, Z.; Liu, Y.; Wu, J.; He, D. The bactericidal and aromatic substance of volatile gas of the plant. Ecol. Environ. 2007, 16, 1455-1459. [CrossRef]

32. Zhou, Y.; Chen, S.; Fan, G.; Wang, Z.; Hou, X. Inhibitory activity of citral derivatives against plant pathogens. Jiangsu Agric. Sci. 2014, 42, 81-83. [CrossRef]

33. Xie, H.; Liu, T.; Chen, J.; Yang, Z.; Xu, S.; Fan, Y.; Zeng, J.; Chen, Y.; Ma, Z.; Gao, Y.; et al. Activation of PSGR with $\beta$-Ionone Suppresses Prostate Cancer Progression by Blocking Androgen Receptor Nuclear Translocation. Cancer Lett. 2019, 453, 193-205. [CrossRef] [PubMed]

34. Shi, C.; Yin, Z.; Wei, Q.; Jia, R. Bacteriostatic Action and Mechanism of a-terpineoi on Escherichia coli. Acta Vet. Et Zootech. Sin. 2013, 44, 796-801. [CrossRef]

35. Guo, C.; Bi, J.; Li, X.; Lyu, J.; Xu, Y.; Hu, J. Investigation on the Phenolic Composition, Related Oxidation and Antioxidant Activity of Thinned Peach Dried by Different Methods. LWT 2021, 147, 111573. [CrossRef]

36. Zhang, G.; An, J.; Xu, Z.; Ma, W.; Sun, H.; Chai, S. Study on the Antifungal and Stability of 7-hydroxycoumarin. J. Southwest For. Univ. 2022, 42, 1-6. [CrossRef]

37. Hu, W.; Huang, C.; Wang, M.-H. Chemical Composition, Nutritional Value, and Antioxidant Constituents of Kalopanax pictus Leaves. Food Chem. 2012, 131, 449-455. [CrossRef]

38. Moo-Huchin, V.M.; Estrada-Mota, I.; Estrada-León, R.; Cuevas-Glory, L.; Ortiz-Vázquez, E.; y Vargas, M.D.L.V.; Betancur-Ancona, D.; Sauri-Duch, E. Determination of Some Physicochemical Characteristics, Bioactive Compounds and Antioxidant Activity of Tropical Fruits from Yucatan, Mexico. Food Chem. 2014, 152, 508-515. [CrossRef]

39. Almeida, M.M.B.; de Sousa, P.H.M.; Arriaga, Â.M.C.; do Prado, G.M.; de Magalhães, C.E.; Maia, G.A.; de Lemos, T.L.G. Bioactive Compounds and Antioxidant Activity of Fresh Exotic Fruits from Northeastern Brazil. Food Res. Int. 2011, 44, $2155-2159$. [CrossRef]

40. Alam, M.N.; Bristi, N.J.; Rafiquzzaman, M. Review on in Vivo and in Vitro Methods Evaluation of Antioxidant Activity. Saudi Pharm. J. 2013, 21, 143-152. [CrossRef]

41. García-Mariño, N.; de la Torre, F.; Matilla, A.J. Organic Acids and Soluble Sugars in Edible and Nonedible Parts of Damson Plum (Prunus domestica L. Subsp. Insititia Cv. Syriaca) Fruits During Development and Ripening. Food Sci. Technol. Int. 2008, 14, 187-193. [CrossRef]

42. Liu, X.; Pu, B.; Liu, Y.; Yan, P.; Luo, X. Determination of the Basic Nutritional Ingredient of Plums (Prunus Mume Sieb. et Zucc) in DAYI. Food Res. Dev. 2007, 28, 146-148. [CrossRef]

43. Zhou, B.; Yi, G.; Gan, L.; Wu, H.; Li, B.; Xie, Y.; Huang, Y.; Zhang, H. Identification and Evaluation of Main Characters of Japanese Apricot Germplasm Resources in Guangdong Province. J. Plant Genet. Resour. 2010, 11, 540-547.

44. Jiang, C.; Ye, X.; Lin, Y.; Fang, Z.; Zhou, D. Analysis and Evaluation of Fruit Nutritional Quality and Aroma Components of Four Major Japanese Apricot (Prunus mume Sieb. et Zucc.) Cultivars in Fujian Province. Food Sci. 2021, 42, $276-283$. 
45. Luo, W.; Tappi, S.; Wang, C.; Yu, Y.; Zhu, S.; Dalla Rosa, M.; Rocculi, P. Effect of High Hydrostatic Pressure (HHP) on the Antioxidant and Volatile Properties of Candied Wumei Fruit (Prunus mume) During Osmotic Dehydration. Food Bioprocess Technol. 2019, 12, 98-109. [CrossRef]

46. Han, X.; Zhao, Y.; Hu, B.; Yang, H.; Peng, Q.; Tian, R. Influence of Different Yeast Strains on the Quality of Fermented Greengage (Prunus mume) Alcoholic Beverage and the Optimization of Fermentation Conditions. LWT 2020, 126, 109292. [CrossRef]

47. Song, S.; Wang, X.; Gao, Z. Inhibitory Activity on Food Borne Pathogens and LC-MS Analysis of Ethyl Acetate Extracts from Fruits of Prunus mume. J. Chin. Inst. Food Sci. Technol. 2020, 20, 307-314. [CrossRef]

48. Haminiuk, C.W.I.; Maciel, G.M.; Plata-Oviedo, M.S.V.; Peralta, R.M. Phenolic Compounds in Fruits-An Overview. Int. J. Food Sci. Technol. 2012, 47, 2023-2044. [CrossRef]

49. Nowak, H.; Kujawa, K.; Zadernowski, R.; Roczniak, B.; KozŁowska, H. Antioxidative and Bactericidal Properties of Phenolic Compounds in Rapeseeds. Lipid/Fett 1992, 94, 149-152. [CrossRef] 